\title{
A meninice mentida e o futuro profanado: as narrativas de Valêncio Xavier
}

Fernanda Borges ${ }^{1}$

Valêncio Xavier, apelidado por Joca Reiners Terron como o Frankenstein de Curitiba (em paralelo a Dalton Trevisan, o Vampiro de Curitiba), escreveu uma série de narrativas visuais, híbridas, em que as imagens muitas vezes estão dispostas de modo a constituir um álbum, um necrológio autoficcional, no qual a memória e a realidade são profanadas com ironia e humor. Nascido em São Paulo, mas radicado durante grande parte de sua vida em Curitiba, Valêncio Xavier faleceu em 2008, deixando-nos várias obras a serem lidas e redescobertas, pois muitos de seus livros foram publicados por pequenas editoras e diversas vezes financiados pelo próprio autor. Duas de suas obras, analisadas neste ensaio, Meu $7^{\circ}$ dia: uma novella rébus (1999) e Minha mãe morrendo e o menino mentido (2001), ilustram tais características marcantes em um diálogo nada convencional, bem como ratificam a importância do autor para a literatura brasileira contemporânea.

\section{O contemporâneo e a profanação}

Dois conceitos do filósofo italiano Giorgio Agamben são norteadores para discutir a literatura de Valêncio Xavier: o de contemporâneo e o de profanação. Tais ideias fazem-se presentes nas obras de Xavier, uma vez que são atravessadas por diversos discursos e campos de saber, assim como a obra de Agamben de um modo geral, e demonstram que a questão da arte no século XXI não é apenas estética, mas ética, lógica, ontológica, política.

No ensaio "O que é o contemporâneo?", Giorgio Agamben (2009) apresenta uma definição de "contemporâneo" bastante inovadora e um tanto quanto paradoxal, principalmente se pensarmos que a visão geral das pessoas sobre tal conceito diz respeito a uma noção de pertencimento e de identificação com "o seu tempo", o tempo presente. O contemporâneo, a partir do senso comum, seria aquele que partilha das ideias, dos costumes e das práticas identificadas como específicas dos "dias de hoje", ou seja,

\footnotetext{
${ }^{1}$ Doutoranda em teoria da literatura na Pontifícia Universidade Católica do Rio Grande do Sul (PUCRS), Porto Alegre, RS, Brasil. Bolsista CNPq. E-mail: fernanda_etc@hotmail.com
} 
aquele que pertence à geração e à história presentes. No entanto, para Agamben, o contemporâneo é um conceito limiar, por refletir a temporalidade, e não o tempo cronológico, e por considerar o anacrônico, o passado e a vanguarda como constituintes de tal concepção.

$\mathrm{O}$ autor inicia o texto expondo sua indagação: "A pergunta que gostaria de escrever no limiar deste seminário é: 'De quem e do que somos contemporâneos? E, antes de tudo, o que significa ser contemporâneo?'” (Agamben, 2009, p. 57). A partir das ideias de Roland Barthes ("O contemporâneo é o intempestivo") e de Nietzsche (é contemporâneo aquele que não coincide perfeitamente com o seu tempo), Agamben explica que o anacrônico faz parte do contemporâneo por ter a percepção da temporalidade, por sua "inatualidade" ser fundamental para apreender o seu tempo.

A contemporaneidade, portanto, é uma singular relação com o próprio tempo, que adere a este e, ao mesmo tempo, dele toma distâncias; mais precisamente, essa é a relação com o tempo que a este adere através de uma dissociação e um anacronismo. Aqueles que coincidem muito plenamente com a época, que em todos os aspectos a esta aderem perfeitamente, não são contemporâneos porque, exatamente por isso, não conseguem vê-la, não podem manter fixo o olhar sobre ela (Agamben, 2009, p. 59).

Assim, segundo Agamben, "contemporâneo é aquele que mantém fixo o olhar no seu tempo, para nele perceber não as luzes, mas o escuro" (Agamben, 2009, p. 62). Perceber o escuro é perceber a falta, a ausência, a lacuna. É estar atento àquilo que não está evidente, que não é óbvio, que não está necessariamente no comércio, na televisão, no catálogo das grandes editoras, por exemplo. Ainda, perceber o escuro, as trevas, é desvendar não ditos e ser interpelado por eles, ou seja, é assumir o não pertencimento e a não identificação com sua época, é sentir-se estranho, estrangeiro, perante supostas naturalidades e perante fatos tidos como óbvios e corriqueiros. Ser contemporâneo é sentir-se anacrônico e, por essa razão, ter o distanciamento necessário para compreender e analisar o tempo presente.

O contemporâneo "tem sempre a forma de um limiar inapreensível entre um 'ainda não' e um 'não mais'” (Agamben, 2009, p. 67). Entre passado e futuro, e influenciado por ambos, o contemporâneo define-se como paradoxal, de acordo com o ensaio de Giorgio Agamben, sobretudo se o compararmos ao conceito padrão de "tempo atual" e 
"nosso tempo". O contemporâneo, neste caso, seria questionar: o tempo atual é o nosso tempo?

Isso significa que o contemporâneo não é apenas aquele que, percebendo o escuro do presente, nele apreende a resoluta luz; é também aquele que, dividindo e interpolando o tempo, está à altura de transformá-lo e de colocá-lo em relação com os outros tempos, de nele ler de modo inédito a história, de "citá-la" segundo uma necessidade que não provém de maneira alguma do seu arbítrio, mas de uma exigência à qual ele não pode responder (Agamben, 2009, p. 72).

Desse modo, o contemporâneo define-se como tal não devido a uma soma de características postuladas ou decodificadas de forma estruturalista, por exemplo, mas em razão de exigências sociais, históricas, subjetivas, ideológicas presenciadas por aquele que vive o tempo presente, identificando-se ou não com ele. Independentemente disso, são os olhos dos leitores, dos espectadores, que irão definir seus próprios conceitos de contemporaneidade na arte e na vida.

O ensaio de Agamben abre novas perspectivas para pensarmos sobre a contemporaneidade, seja literária ou não. As ideias trazidas pelo texto (nem tão novas assim, já que remodeladas a partir de Barthes e Nietzsche) ilustram perfeitamente a reflexão proposta por Agamben: Barthes e Nietzsche são contemporâneos sob esse ponto de vista, pois o filósofo italiano iluminou-os para trazer-nos diferentes abordagens em relação às mais tradicionais. Cabe-nos perguntar, portanto, o que estamos iluminando em nossas discussões acadêmicas. Estamos realmente olhando para as trevas, para os pontos escuros a fim de trazêlos à luz, ou ainda iluminamos os mesmos assuntos e autores? Somos contemporâneos verdadeiramente, a partir da concepção de Agamben, ou somente no momento de discutir teoricamente?

Giorgio Agamben, em outro ensaio, intitulado "Elogio da profanação" (2007), dedica-se a refletir sobre o que é a profanação e a explicá-la, retomando primeiramente conceitos do direito romano e do cristianismo. Partindo da definição de "sagrado" como aquilo que está indisponível e distante dos homens, ou seja, como o que é inacessível e que está separado dos seres humanos por ser do âmbito da divindade, o autor define o ato profanatório como aquele que restitui ao uso livre dos homens o que era restrito à esfera do sagrado e, portanto, inalcançável aos indivíduos ordinários. Profanar, de acordo com Agamben, é 
desmitificar, é tornar possível uma aproximação até então improvável entre elementos pertencentes a áreas diversas, é contrabandear ideias, conceitos, comportamentos, experiências.

Puro, profano, livre dos nomes sagrados, é o que é restituído ao uso comum dos homens. Mas o uso aqui não aparece como algo natural; aliás, só se tem acesso ao mesmo através de uma profanação. Entre "usar" e "profanar" parece haver uma relação especial, que é importante esclarecer (Agamben, 2007, p. 65).

Segundo o autor, "A passagem do sagrado ao profano pode acontecer também por meio de um uso (ou melhor, de um reúso) totalmente incongruente do sagrado. Trata-se do jogo." (2007, p. 66) Derivado de cerimônias e rituais religiosos, o jogo opera uma suspensão no utilitarismo cotidiano. Os jogos com bola, por exemplo, reproduziam as lutas dos deuses pela posse do sol, bem como muitas brincadeiras infantis também reproduzem comportamentos adultos:

O jogo libera e desvia a humanidade da esfera do sagrado, mas sem a abolir simplesmente. O uso a que o sagrado é devolvido é um uso especial, que não coincide com o consumo utilitarista. Assim, a "profanação" do jogo não tem a ver apenas com a esfera religiosa. As crianças, que brincam com qualquer bugiganga que lhes caia nas mãos, transformam em brinquedo também o que pertence à esfera da economia, da guerra, do direito e das outras atividades que estamos acostumados a considerar sérias. Um automóvel, uma arma de fogo, um contrato jurídico transformamse improvisadamente em brinquedos. (Agamben, 2007, p. 67).

Afinal de contas, por que se participa de um jogo? Por que uma criança pode brincar com qualquer objeto? Por que um gato brinca com um novelo de lã? Porque o jogo, a partir da profanação de qualquer finalidade pragmática, é "a porta de uma nova felicidade" (Agamben, 2007 , p. 67). O jogo, portanto, profana o que estava indisponível para uso a fim de transformar essa distância e essa separação em uma experiência presente, isto é, em algo possível e próximo de ser experienciado, cuja satisfação está no ato em si, não somente em sua conclusão.

O jogo com o novelo representa a libertação do rato do fato de ser uma presa, e é a libertação da atividade predatória do fato de estar necessariamente voltada para a captura e a morte do rato; apesar disso, ele apresenta os mesmos comportamentos que definiam a caça. A atividade que daí resulta torna-se dessa forma 
um puro meio, ou seja, uma prática que, embora conserve tenazmente a sua natureza de meio, se emancipou da sua relação com uma finalidade, esqueceu alegremente o seu objetivo, podendo agora exibir-se como tal, como meio sem fim. Assim, a criação de um novo uso só é possível ao homem se ele desativar o velho uso, tornando-o inoperante. (Agamben, 2007, p. 74-75).

No entanto, Agamben afirma que o jogo como profanação está em decadência na contemporaneidade. As pessoas seguem jogando, mas com uma finalidade, com uma mentalidade pragmática: "A possibilidade de voltar à festa perdida, um retorno ao sagrado e aos seus ritos, mesmo que fosse na forma das insossas cerimônias da nova religião espetacular ou de uma aula de tango em um salão do interior" (Agamben, 2007, p. 68). Desse modo, o jogo não mais é puro meio, não mais é puramente diversão e alegria, mas a tentativa de ganho, de lucro, de reconhecimento. O autor afirma ainda: "Nesse sentido, os jogos televisivos de massa fazem parte de uma nova liturgia, e secularizam uma intenção inconscientemente religiosa. Fazer com que o jogo volte à sua vocação puramente profana é uma tarefa política" (Agamben, 2007, p. 68).

O jogo cuja motivação é a vitória, o dinheiro, o status ou a salvação de um modo geral é um retorno aos rituais religiosos e a uma perspectiva que evidencia a necessidade de algo a ser cultuado e de alguém que o cultue. Quebrar essa lógica por meio do lúdico, fazendo um reúso de sistemas cartesianos, hierárquicos ou capitalistas, é a tarefa a que Agamben nos incumbe, pois é no cotidiano de trabalho, de estudo, de família, de amor e desamor que é possível modificarmos, pouco a pouco, tais sistemas de ação e de pensamento. Selvino Assmann, na apresentação do livro Profanações, de Giorgio Agamben, sintetiza tal tarefa política discutida pelo filósofo: "Profanar é assumir a vida como jogo" (Assmann, 2007, p. 13).

Profanar não significa simplesmente abolir e cancelar as separações, mas aprender a fazer delas um novo uso, a brincar com elas. A sociedade sem classes não é uma sociedade que aboliu e perdeu toda memória das diferenças de classe, mas uma sociedade que soube desativar seus dispositivos, a fim de tornar possível um novo uso, para transformá-las em meios puros (Agamben, 2007, p. 75).

É exatamente pela lembrança, pela memória, que sabemos o que devemos profanar e como fazer isso. A percepção do que a sociedade considera sagrado e do que as convenções estipulam como tal é o 
primeiro passo para o projeto estético-político proposto por Agamben. Do mesmo modo, é imprescindível que reconheçamos, e jamais nos esqueçamos de rememorar, o objetivo da mídia de neutralizar os ditos meios puros, como a linguagem.

$\mathrm{Na}$ sua fase extrema, o capitalismo não é senão um gigantesco dispositivo de captura dos meios puros, ou seja, dos comportamentos profanatórios. Os meios puros, que representam a desativação e a ruptura de qualquer separação, acabam por sua vez sendo separados em uma esfera especial. Exemplo disso é a linguagem. Certamente o poder sempre procurou assegurar o controle da comunicação social, servindo-se da linguagem como meio para difundir a própria ideologia e para induzir a obediência voluntária. Hoje, porém, tal função instrumental - ainda eficaz às margens do sistema - deu lugar a um procedimento diferente de controle, que, ao ser separado na esfera espetacular, atinge a linguagem no seu rodar no vazio, ou seja, no seu possível potencial profanatório. Mais essencial que a função de propaganda, que diz respeito à linguagem como instrumento voltado para um fim, é a captura e a neutralização do meio puro por excelência, isto é, da linguagem que se emancipou dos seus fins comunicativos e assim se prepara para um novo uso (Agamben, 2007, p. 76).

Para Agamben, é necessário impedir que os dispositivos midiáticos se apropriem de tais meios puros, que, por definição, seriam inapropriáveis. Como fazer isso? A partir de uma profanação anterior, da neutralização pela profanação, nesse caso específico. Novamente nos perguntamos: como fazer isso? Mais que negar e ignorar os dispositivos midiáticos, para neutralizá-los, precisamos combatê-los por meio de sua subversão, ou seja, por meio de um novo uso, de um reúso que evidentemente estabeleça não só um contraste com tais dispositivos nesses mesmos dispositivos, mas também uma paródia sobre eles. Além de neutralizar e de aprisionar as intenções profanatórias, o Improfanável nos distrai de tais intenções, de tais necessidades de profanação. É contra essa distração constante em que vivemos que a linguagem e a literatura devem nos ajudar a lutar, pois "a profanação do improfanável é a tarefa política da geração que vem" (Agamben, 2007, p. 79). Nada impede, entretanto, que esta geração comece a assumir tal atribuição, pois, como afirma Assmann, "isso equivale a ir em busca da infância, ou seja, de nossa capacidade de jogar e de amar" (Assmann, 2007, p. 7). Se o convite à profanação representa um retorno à 
infância, ela é também um exercício da memória quanto às características fundamentais de ser criança, pois é somente recordando os atributos infantis que se torna possível entender o que é a profanar e em que isso consiste. Assmann afirma ainda que "as crianças sabem jogar e brincar, enquanto os adultos, sérios, perderam a capacidade de serem mágicos e de fazerem milagres" (Assmann, 2007, p. 13). A literatura de Valêncio Xavier devolve-nos a magia que foi perdida por esses adultos sérios. Essa restituição, artística acima de tudo, ocorre tanto por meio do retrato dessa perda quanto por meio do exercício infantil da magia, exposto por narradores que não desaprenderam a profanar.

A escritura e a literatura, a princípio, já têm intenções profanatórias: a primeira por se constituir como puro meio, e a segunda por, a partir de um jogo propiciado por tal meio, realizar um deslocamento e um despertar da distração que os dispositivos midiáticos insistem em impor. Contudo, a literatura também perde essa definição à medida que se torna mais um instrumento dos dispositivos neutralizadores, pois, ao reproduzir valores dominantes, patriarcais, segregadores e estereotipados, também passa a ser um agente de neutralização da linguagem, um agente de neutralização de um meio puro, o qual deveria ser um convite à profanação, e não um simples difusor de estereótipos introjetados na sociedade há muito tempo. Desse modo, é a valorização de uma literatura profanatória que subverta essa mentalidade alienante e neutralizadora que também deve se fazer presente a fim de que a tarefa política a que Agamben se refere seja minimamente realizada. Os instrumentos artísticos são, por definição, um dos principais responsáveis pela profanação do lugar comum social e assim devem continuar sendo. Um novo uso da e para a literatura é o que as obras de Valêncio Xavier se propõem a fazer.

Diversos são os conceitos utilizados, tanto por leitores quanto por críticos e teóricos, para definir o que é a boa ou a má literatura. A definição proposta neste ensaio pauta-se na necessidade de leitura e de estudo de uma literatura contemporânea e profanatória.

\section{Álbuns da infância e da morte}

A obra de Valêncio Xavier passou a ter mais circulação em 1998, quando a editora Companhia das Letras publicou uma reunião de textos 
do escritor sob o título $O$ mez da grippe e outros livros² (os quais haviam sido publicados separadamente), e em 2001, com a edição de Minha mãe morrendo e o menino mentido, composta por "Minha mãe morrendo", "Menino Mentido - topologia da cidade por ele habitada" e "Menino mentido", "o Valêncio Xavier dos anos 2000", como ele mesmo costumava se referir à obra. Os três textos dessa publicação podem ser lidos separadamente (cada um deles como uma novela, por exemplo) ou podem ser lidos como capítulos de um romance, uma vez que têm o mesmo narrador: um homem que relembra momentos de sua infância. $\mathrm{O}$ menino mentido pela passagem do tempo, pelas armadilhas da memória e pela sedução da narração surpreende-nos com sua sintaxe verbal e visual ao retratar suas inquietações, suas alegrias e tristezas a partir de vários meios e artefatos presentes em sua infância, como imagens de propagandas e de atrizes famosas da época, fotografias, desenhos.

Em Meu $7^{0}$ dia: uma novella rébus, publicado em 1999 pelas Edições Ciência do Acidente, o escritor justapõe imagens antigas de revistas, ilustrações de um livreto religioso, bem como letras de canções populares e textos de sua autoria, para narrar a sua própria morte, fazer o seu acerto de contas com Deus e cobrar dos leitores por que não compareceram ao seu enterro. Ademais, como uma novela rébus, há a proposta de resolução de um enigma presente na narrativa; tal adivinha, no entanto, é descrita pelo autor como indecifrável. O tema da morte, que perpassa toda sua obra, une as duas publicações: em $\mathrm{Meu} 7^{\circ}$ dia: uma novella rébus, temos notícia do falecimento de um tal de Valêncio Xavier e, em Minha mãe morrendo e o menino mentido, é a morte da mãe do narrador que nos é contada a partir de um álbum com fotografias familiares, diversas pinturas e imagens. A morte, assunto recorrente nos livros do escritor e retratada a partir de imagens e textos jornalísticos, os quais ilustram a violência urbana, bem como a reconstituição de crimes antigos e recentes ${ }^{3}$, não é abordada com tal enfoque nas narrativas aqui analisadas. Nestas, a ideia de morte é dessacralizada, profanada, de acordo com as reflexões do filósofo Giorgio Agamben, pois é descrita como um acontecimento mundano, quase banal, ao ser suspensa da atmosfera cerimonialista, própria dos enterros e funerais.

\footnotetext{
${ }^{2}$ Essa publicação recebeu em 1999 o Prêmio Jabuti de Melhor Produção Editorial.

${ }^{3}$ A morte gerada pela violência é retratada, por exemplo, nas obras Crimes à moda antiga (2004) e Rremembranças da menina de rua morta nua e outros livros (2006).
} 
As colagens e montagens de Valêncio Xavier e sua escrita fragmentada, que desafiam o leitor a participar do jogo proposto, a desafiar o enigma da narrativa (um enigma que "esqueceu alegremente o seu objetivo" (Agamben, 2007, p. 75), sem qualquer outra finalidade a não ser a diversão e o desafio do pensamento), profanam não só as estruturas e formas narrativas - bem como o livro como suporte da literatura - mas também temas e abordagens, desenvolvendo um jogo que nos diverte duplamente: por surpreender nossos olhos a cada vez que viramos a página e por brincar com assuntos geralmente discutidos com tons graves e sérios, como a morte.

As intervenções nada livrescas de Valêncio Xavier podem ser tomadas como profanatórias, sobretudo por causa de sua insistência na dissecção minuciosa dos corpos, sem poupar muito pelo contrário - aquele de sua própria mãe, insuflado pela célebre série de desenhos de Flávio de Carvalho, intitulada "Minha mãe morrendo" (Wolff, 2013, p. 250).

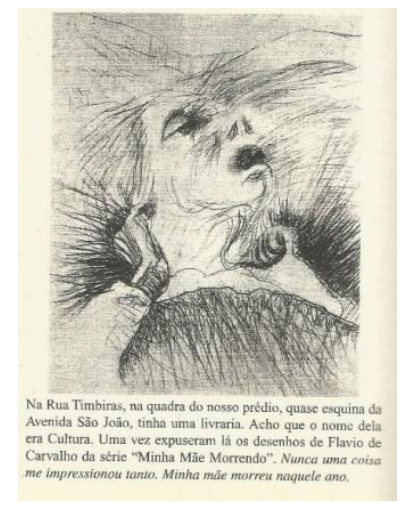

Figura 1: desenho de Flávio de Carvalho.

Em Minha mãe morrendo e o menino mentido, o desenho da série "Minha mãe morrendo", de Flávio de Carvalho, está presente na segunda parte da narrativa, "Menino mentido - topologia da cidade por ele habitada". Porém, a série de desenhos intitula a primeira parte do livro, em que o narrador relembra a morte da mãe, contrapondo duas imagens: a da mãe nua, vista pela fresta da porta do banheiro, e a da mãe morta, nua, na mesa de cirurgia. 

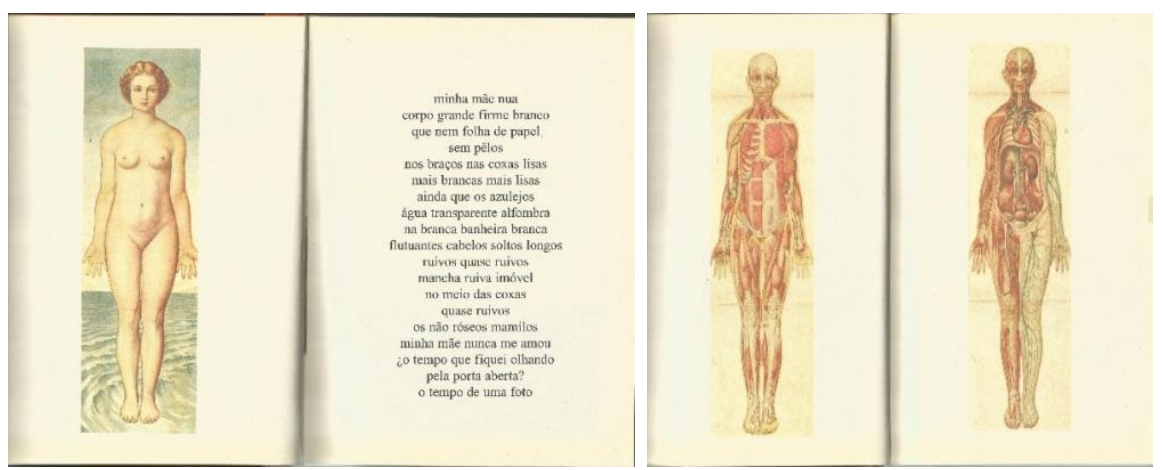

Figura 2: imagens paradoxais para o narrador.

O corpo da mãe, como conceito, é dessacralizado na abordagem de Valêncio Xavier, embora o escritor exponha imagens genéricas do corpo humano para representar Maria, sua mãe, e não brinque com a morte dela ou a ironize, como faz ao pensar a sua própria morte em $\mathrm{Meu} 7^{\circ} \mathrm{dia}$. Ele nos revela o quanto sofreu com a distância materna e com a sensação de não ser suficientemente amado por uma mulher que se casou por convenção e teve tuberculose.
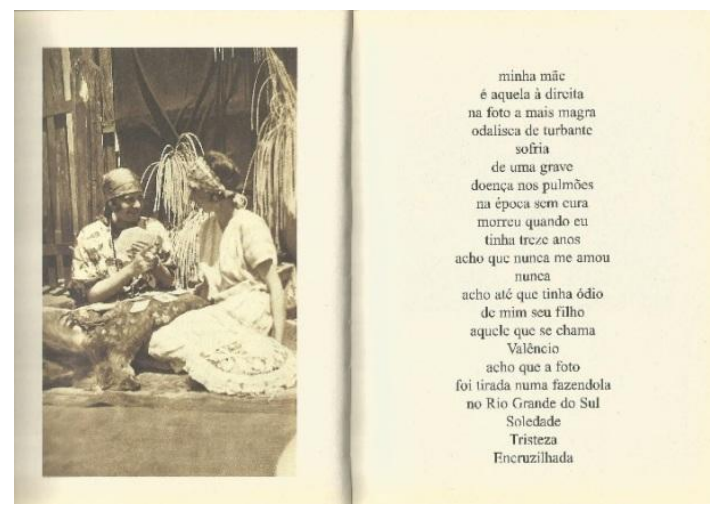

Figura 3: fotografia da mãe do narrador.

Retrato diferente acerca da morte materna é o que faz Roland Barthes em algumas obras. Uma de suas reflexões em Diário de luto (2011), livro de notas acerca da dor de perder sua mãe, com quem tinha um 
relacionamento próximo e afetuoso, expõe-nos a perspectiva de quem observa o cansaço do corpo doente. Em 27 de outubro de 1977, Barthes escreve: "-Você não conheceu o corpo da Mulher!/ - Conheci o corpo de minha mãe doente, depois agonizante" (2011, p. 4). Já em 4 de novembro de 1977, é outra imagem que vem à mente do escritor: "Esta noite, pela primeira vez, sonhei com ela; estava deitada, mas não doente, com sua camisola cor-de-rosa comprada no Uniprix [...]"(2011, p. 34) As duas imagens, a da mãe saudável e a da mãe doente, também são recorrentes para Barthes, o que pode demonstrar um sentimento de caráter geral, presente em todas as pessoas que acompanharam a saúde e a morte de alguém. O carinho de Barthes por sua mãe também está muito presente em Roland Barthes por Roland Barthes (2003), em que o autor, além de refletir sobre sua obra, presenteia-nos com uma série de fotografias de diversas épocas de sua vida e de membros da família. O espaço reservado para falar sobre sua mãe e para expor suas fotografias é priorizado em muitos momentos pelo teórico, o qual enfatiza passagens da infância e da adolescência feliz que sua mãe pôde lhe proporcionar.

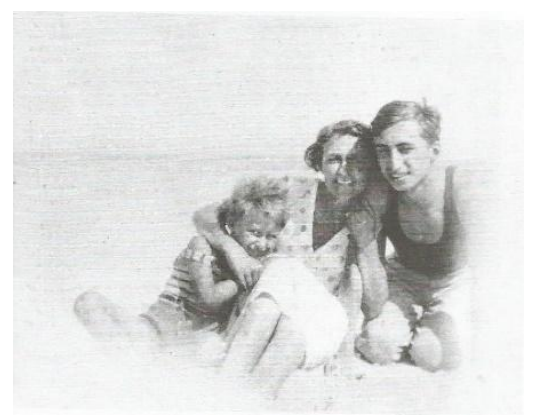

Figura 4: "A família sem o familialismo".

Valêncio Xavier, no entanto, em Minha mãe morrendo e o menino mentido , não seleciona nenhuma foto em que apareça junto de sua mãe - ou que uma criança esteja ao lado de uma mulher que possa ser sua mãe (se partirmos do pressuposto autoficcional ou da meninice mentida do narrador do livro). Se, neste caso, o luto é um elemento compartilhado, a relação familiar que gera a reação à perda é de caráter diverso nos dois autores. $\mathrm{O}$ menino mentido de Valêncio Xavier é um 
menino solitário, porém, ou exatamente devido a isso, muito divertido e criativo, que, talvez também pelo falecimento da mãe, tem certa obsessão pela morte - mas não por "qualquer morte", especificamente pela de Lampião e Maria Bonita. As histórias do bando de Lampião ressurgem por diversas vezes em meio à coleção de memórias do narrador, que relembra sua infância intercalando a trajetória do Rei do Cangaço narrada na literatura de cordel e nas páginas de jornal.

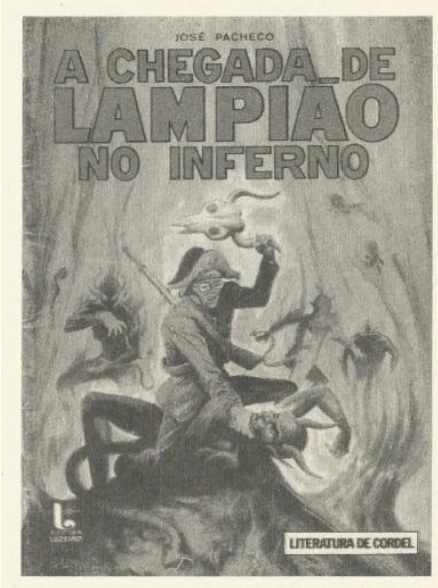

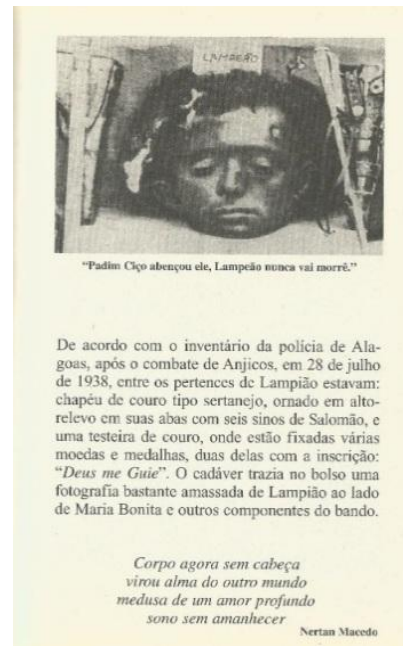

Figura 5: O Lampião do cordel e o Lampião do jornal.

Um álbum sobre a morte da mãe, um álbum sobre as recordações da infância, com as histórias e imagens que constituíram o adulto que se reinventa no passado, que mente suas memórias, que faz literatura. Pode-se considerar, portanto, que tais álbuns constituem-se como um diário do narrador, diário mentido e tardio talvez, mas que são uma coleção de possíveis histórias e de imagens reais, familiares, momentos de sua trajetória.

Em "Cartões-postais, álbuns de família e ícones da intimidade", Nelson Schapochnik (1998, p. 462) explica que as fotografias relacionadas à família têm "um valor de culto", por estarem costumeiramente bastante acessíveis aos nossos olhos: em porta-retratos sobre os móveis, em quadros nas paredes e em de nossas carteiras. No entanto, a relação do narrador de Valêncio Xavier (2001) com as fotografias de seu álbum de 
família não apresenta somente tal valor de culto. Os sentimentos paradoxais em relação à mãe e à morte dela encerram o primeiro capítulo deste álbum narrativo ("Minha mãe morrendo"), o que faz com que queira libertar-se de tais imagens. $O$ narrador, refletindo sobre o fato de que não sabe o que sentiu na infância quando viu sua mãe nua certa vez, contrapõe tal imagem à da mãe morta em uma mesa de cirurgia. Essas São duas imagens que não lhe saem da cabeça e que se constituíram, assim, como parte da história sobre o menino "que não deu certo - ovo que gorou" (Xavier, 2001, p. 219).

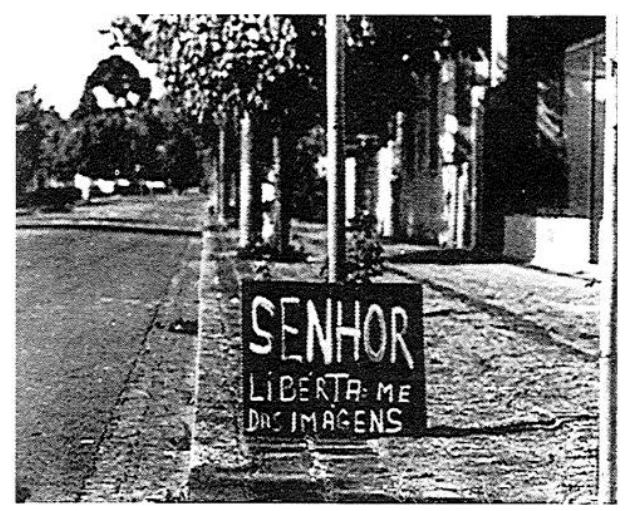

Figura 6: Imagem final de "Minha mãe morrendo".

Nelson Schapochnik afirma que a fotografia é a história visual da família. Se apenas uma fotografia já tem características narrativas, embora se constitua, muitas vezes, mais como descrição de uma cena do que propriamente como narração de um episódio, a organização de diversas fotografias em uma certa ordem, em um álbum, dá-lhe efetivamente $\mathrm{o}$ atributo de narrativa visual.

Talvez uma das características de um álbum de família seja o fato de ele se apresentar como uma obra aberta. Embora o guardião da iconoteca familiar se esforce para preservar o acervo e imprimir uma lógica no seu ordenamento, algumas peças podem ser perdidas, outras podem ser acrescentadas e, ao fim e ao cabo, a sua própria morte propiciará uma redistribuição e a "invenção" de uma nova crônica familiar (Schapochnik, 1998, p. 463). 
Se, no primeiro capítulo do álbum, o narrador dedica-se a relembrarse de sua mãe e a explicar-nos como era sua relação com ela, nos demais capítulos ("Menino mentido - topologia da cidade por ele habitada" e "Menino mentido"), acrescenta uma série de novas imagens, as quais vão constituir desta vez não um álbum de família, mas um álbum sobre o passado infantil, no qual a coleção de figurinhas da meninice transforma-se em relíquia na vida adulta. Flora Süssekind, no prefácio de $\mathrm{Meu} 7^{\circ}$ dia, intitulado "Memento mori", reflete sobre a obra de Valêncio Xavier e sintetiza as principais características do álbum de Minha mãe morrendo e o menino mentido:

Um volume à parte, atribuindo função narrativa peculiar ao movimento sucessivo das páginas, à repetição das figuras. O que, no caso da novela mais recente, intensifica uma tensão entre texto e imagem, entre a primeira pessoa narrativa, as fotos de álbum de família, o dado memorialista, e uma sequência de figuras tiradas de lições escolares de anatomia, figuras anônimas, simplificadas, descarnadas, com os órgãos à mostra, depois refiguradas e repetidas, repetidas de novo. Imbricando-se, assim, ao movimento aparentemente subjetivo, particularizador, da lembrança, a seca tipificação, a abstratização anônima da imagem cadavérica (Süssekind, 1999, p. 5).

Meu $7^{\circ}$ dia: uma novella rébus é como se fosse o segundo volume desse álbum, dessa coleção, pois agora o narrador Valêncio Xavier, "o guardião da iconoteca familiar", reflete sobre sua morte à la Brás Cubas. Ele mesmo reinventa a crônica de uma vida e, a partir de imagens de um antigo fascículo religioso, sugere-nos a sua ressurreição. $\mathrm{O}$ texto inicia com um anúncio incompleto acerca "do sempre lembrado Valêncio Xavier" e que sugere a sua morte. A partir de imagens que remetem biblicamente à criação do mundo, o narrador-defunto compara a sua criação à criação divina, suas lembranças às do "Creador" e seus sete dias de trabalho, enfatizando a saudade da amada, que está distante. A "dor de cotovelo" também pode ser uma das chaves de leitura do texto, como afirma o próprio autor em entrevista à Folha de $S$. Paulo em 1999.

Folha - "Meu $7^{\circ}$ Dia" conta uma história de desilusão amorosa? Xavier - É. O livro pode parecer tratar de um acerto de contas meu com Deus, mas isso é apenas o começo do livro. Folha - Não seria um acerto de contas seu consigo mesmo? 
Xavier - Acho que sim. Tudo o que escrevo é na primeira pessoa. Estou falando no livro do meu sétimo dia. De minha morte. Folha - E quando foi esse seu sétimo dia? Xavier - Não vejo diferença entre a coisa inventada e a acontecida. Minha morte pode não ter acontecido, mas no livro acontece. Então ela existe. Se me dou ao trabalho de escrever sobre uma desilusão amorosa falsa, ela passa a ser verdadeira. Aqui trato de uma coisa inventada. Mas o autor, queira ou não, teve que passar por todo o sofrimento da desilusão amorosa. Quem toma um fora morre (Xavier, 1999, s.p.).
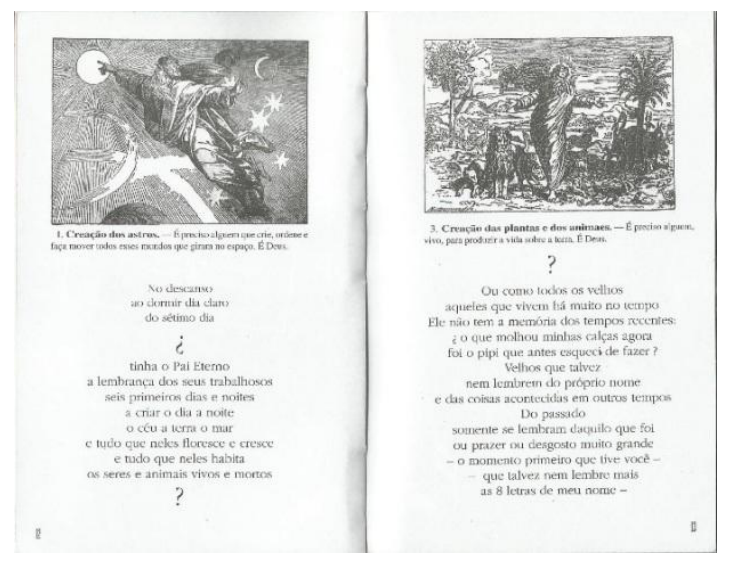

Figura 7: Meu $7^{\circ}$ dia.

Valêncio Xavier, autor-narrador-personagem dos dois livros aqui analisados, mescla ficção e realidade em um gênero híbrido e contemporâneo: a autoficcção. Esse conceito foi criado em 1977 por Serge Doubrovsky para definir seu romance Fils, cujo tema é sua própria vida. Ele caracteriza seu livro como autoficcional, e não como autobiográfico, pois realiza uma ficção de eventos e de fatos reais, ou seja, transforma a realidade em ficção a partir do uso da linguagem. Desse modo, a liberdade de escrever sobre si e sobre sua vida faz com que o autor recrie a si próprio como narrador e personagem, distanciando-se do compromisso de verdade e de realidade para transformar a si mesmo em literatura, como afirma Valêncio Xavier na 
entrevista concedida à Folha de S.Paulo. A "ficcionalização de si" na obra do autor recebe um tom mais realista em Minha mãe morrendo e o menino mentido, por se tratar de uma obra que remete ao passado e às lembranças da infância, e um tom mais irônico e ficcional em $\mathrm{Meu} 7^{\circ}$ dia, por antecipar o futuro e, quem sabe, assim também o profanar.

No sétimo dia, quando Deus teria de descansar (e dar descanso à Valêncio), Ele arquitetou um plano contra o narrador: deixou-o longe do amor de sua vida até mesmo no dia de seu passamento. Valêncio Xavier, autor-narrador-personagem que escreve "torto por linhas certas", como esclarece em Meu $7^{0}$ dia, também não descansa quando, morto, deveria fazê-lo, e desafia-nos a desvendar um enigma, tão difícil, segundo ele, que daria todo o dinheiro do bolso caso alguém o descobrisse, "coisa que ninguém fará".

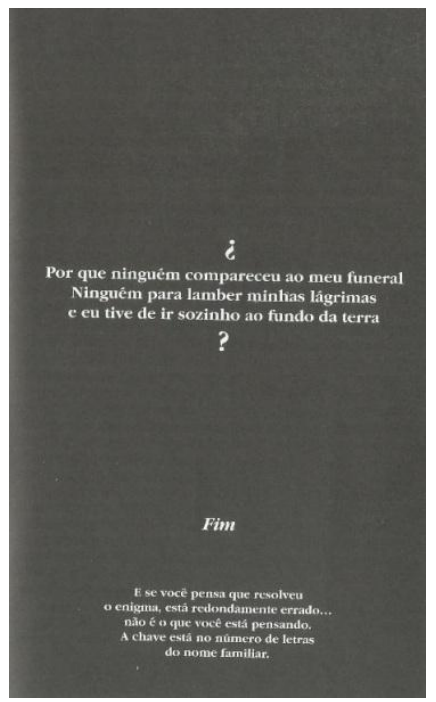

Figura 8: Parte do enigma indecifrável

O enigma criado para si próprio, para a sua diversão exclusiva, ilustra a bela expressão de Giorgio Agamben, pois "esqueceu alegremente o seu objetivo" (Agamben, 2007, p. 75), ou seja, a decifração do mistério. Ela não é importante; importante é tentar realizá-la, lendo e relendo o texto, testando palíndromos, sentidos, interpretações e manuseios. Independentemente de o leitor desvendar ou não tal 
artimanha proposta por Valêncio Xavier, a narrativa continuará profanando a vida, a morte, a leitura. Afinal, é o leitor quem validará ou não tal enigma e o jogo escritural.

$\mathrm{Na}$ escritura múltipla, com efeito, tudo está para ser deslindado, mas nada para ser decifrado; a estrutura pode ser seguida, "desfiada" (como se diz uma malha de meia que escapa) em todas as suas retomadas e em todos os seus estágios, mas não há fundo; o espaço da escritura deve ser percorrido, e não penetrado; a escritura propõe sentido sem parar, mas é sempre para evaporálo: ela procede a uma isenção sistemática do sentido. Por isso mesmo, a literatura (seria melhor passar a dizer a escritura), recusando designar ao texto (e ao mundo como texto) um "segredo", isto é, um sentido último, libera uma atividade a que se poderia chamar contrateológica, propriamente revolucionária, pois a recusa de deter o sentido é finalmente recusar Deus e suas hipóstases, a razão, a ciência, a lei (Barthes, 2012, p. 63).

Roland Barthes, em "A morte do autor" (2012), questiona a concepção centralizadora de autoria e enfatiza o nascimento e a liberdade do leitor para apropriar-se do texto, para desfiá-lo. Assim, descobrir ou não a resposta ao enigma torna-se um caminho de leitura individual de cada leitor, embora tal autonomia e negação das indicações textuais também, de certo modo, corroborem para a certeza do autor-narrador-personagem: ninguém entenderá seu desafio. As concepções de "morte do autor" e de liberdade do leitor também são profanadas em Meu $7^{\circ}$ dia: uma novella rébus, ironizadas em uma narrativa autoficcional em que três papéis são exercidos por um mesmo nome, se não um mesmo referente. Essa volta à centralidade, que se propõe a rivalizar com Deus para substituí-lo, neste caso, é restituir ao uso livre dos homens, aos leitores, uma nova concepção de autoria - é, portanto, ressuscitar o autor.

\section{O prazer do jogo}

Valêncio Xavier faleceu na literatura em 1999 e na vida real nove anos depois. Em 2014, suas obras ainda muito instigam e desafiam o leitor, o que ratifica a afirmação de Décio Pignatari de que "a narrativa visual é muito nova no mundo; Valêncio é pioneiro no mundo todo" (apud Xavier, 1999, s.p.). Pioneiro, por, na década de 1980, por exemplo, já estar completamente imerso no universo das narrativas com colagens 
e superposições textuais, muitas delas reunidas em $O$ mez da grippe $e$ outros livros. Desse modo, sua literatura mostra-se extremamente contemporânea, principalmente se pensarmos o contemporâneo também conforme as ideias de Giorgio Agamben.

Unindo, portanto, dois conceitos fundamentais para pensar a respeito da obra de Valêncio Xavier, o de profanação e o de contemporâneo, talvez seja redundante afirmar: a literatura de Valêncio Xavier é contemporânea por ser profanatória. Por profanar temas, estruturas, suportes; por ser uma literatura cortada, colada, amassada; por mesclar referências populares, eruditas, infantis, religiosas; por devolver o lúdico a adultos tão acostumados a serem sérios e rígidos; por restituir ao leitor o prazer do inesperado de cada página, o prazer da leitura por diversão.

\section{Referências}

AGAMBEN, Giorgio (2007). Elogio da profanação. In: AGAMBEN, Giorgio. Profanações. Tradução de Selvino José Assmann. São Paulo: Boitempo.

AGAMBEN, Giorgio (2009). O que é o contemporâneo? In: AGAMBEN, Giorgio. $O$ que é o contemporâneo? e outros ensaios. Tradução de Vinícius Nicastro Honesko. Chapecó: Argos.

ASSMANN, Selvino José (2007). Apresentação. In: AGAMBEN, Giorgio. Profanações. Tradução de Selvino José Assmann. São Paulo: Boitempo.

BARTHES, Roland (2003). Roland Barthes por Roland Barthes. Tradução de Leyla Perrone-Moisés. São Paulo: Estação Liberdade.

BARTHES, Roland (2011). Diário de luto. Tradução de Leyla Perrone-Moisés. São Paulo: Martins Fontes.

BARTHES, Roland (2012). A morte do autor. In: BARTHES, Roland. O rumor da língua. Tradução de Mario Laranjeira. São Paulo: Martins Fontes.

DOUBROVSKY, Serge (1977). Fils. Paris: Galilée.

SCHAPOCHNIK, Nelson (1998). Cartões-postais, álbuns de família e ícones da intimidade. In: SEVCENKO, Nicolau (Org.). História da vida privada no Brasil. São Paulo: Companhia das Letras. v. 3.

SÜSSEKIND, Flora (1999). Memento mori. In: XAVIER, Valêncio. Meu $7^{0}$ dia: uma novella rébus. São Paulo: Ciência do Acidente. 
XAVIER, Valêncio (1998). O mez da grippe e outros livros. São Paulo: Companhia das Letras.

XAVIER, Valêncio (1999). Frankenstein de Curitiba mostra nova cria literária: entrevista. Folha de S. Paulo, 20 mar. In: XAVIER, Valêncio. Meu $7^{\circ}$ dia: uma novella rébus. São Paulo: Ciência do Acidente.

XAVIER, Valêncio (2001). Minha mãe morrendo e o menino mentido. São Paulo: Companhia das Letras.

XAVIER, Valêncio (2004). Crimes à moda antiga. São Paulo: Publifolha.

XAVIER, Valêncio (2006). Rremembranças da menina de rua morta nua: e outros livros. São Paulo: Companhia das Letras.

WOLFF, Jorge (2013). Valêncio Xavier: o autor como profanador. In: CHIARELLI, Stefania; DEALTRY, Giovanna; VIDAL, Paloma (Org.). O futuro pelo retrovisor. Rio de Janeiro: Rocco.

Recebido em junho de 2014.

Aprovado em outubro de 2014.

\section{resumo/abstract}

\section{A meninice mentida e o futuro profanado: as narrativas de Valêncio Xavier}

Fernanda Borges

As obras de Valêncio Xavier caracterizam-se, em termos formais, pela utilização de diversos tipos de imagens (desenhos, fotografias, artigos de jornal, flip books), elementos que compõem narrativas híbridas. Tais artefatos são organizados de modo a compor um álbum no romance Minha mãe morrendo e o menino mentido e um necrológio em $\mathrm{Meu} 7^{\circ}$ dia: uma novella rébus. Da meninice mentida ao funeral dessacralizado, Valêncio Xavier ilumina e reelabora lembranças infantis e projeta e ironiza o futuro inevitável. Dessa forma, este trabalho tem como objetivo discutir atributos estruturais e temáticos das obras do autor brasileiro a fim de refletir acerca desses álbuns narrativos que criam o passado e o futuro.

Palavras-chave: literatura brasileira contemporânea, profanação, álbum, Valêncio Xavier. 
The lied chidhood and the profaned future: the narratives by Valêncio Xavier

Fernanda Borges

The works of Valêncio Xavier are characterized, in formal terms, by using various types of images (drawings, photographs, newspaper articles, flip books), elements that make hybrid narratives. Such artifacts are arranged in order to compose an album in the novel Minha mãe morrendo e o menino mentido and an obituary in $\mathrm{Meu} 7^{\circ}$ dia: uma novella rébus. From a lied childhood to a desecrated funeral, Valêncio Xavier lights and reworks childhood memories and designs and mocks the inevitable future. Thus, this study aims to discuss structural and thematic attributes of the works of this Brazilian author to reflect on these narrative albums that create the past and the future.

Palavras-chave: contemporary Brazilian literature, profanation, album, Valêncio Xavier. 